\title{
Transformation and transport of inorganic nitrogen in sediments of a southeast Asian mangrove forest
}

\author{
Erik Kristensen ${ }^{1, *}$, Mikael H. Jensen ${ }^{1,2}$, Gary T. Banta $^{3}$, Kim Hansen ${ }^{1}$, \\ Marianne Holmer ${ }^{1}$, Gary M. King ${ }^{4}$ \\ ${ }^{1}$ Institute of Biology, Odense University, DK-5230 Odense M, Denmark \\ ${ }^{2}$ Nature Management and Water Quality Division, County of Fyn, Ørbækvej 100, DK-5220 Odense Sø, Denmark \\ ${ }^{3}$ Department of Life Sciences and Chemistry, Roskilde University, Box 260, DK-4000 Roskilde, Denmark \\ ${ }^{4}$ Darling Marine Center, University of Maine, Walpole, Maine 04573, USA
}

\begin{abstract}
The most important inorganic nitrogen transformations (nitrification, denitrification and $\mathrm{N}$ fixation) and DIN fluxes in darkened and inundated sediments were studied during the dry season in the Ao Nam Bor mangrove forest at the island of Phuket. Thailand. Dark fluxes of $\mathrm{NH}_{4}{ }^{+}$were low (not significantly different from zero) and tended to be directed into the sediment in the area vegetated by the tree Rhizophora apiculata $\left(204 \mu \mathrm{mol} \mathrm{m} \mathrm{m}^{-2} \mathrm{~d}^{-1}\right)$ and out of the sediment in an adjacent unvegetated area $\left(80 \mu \mathrm{mol} \mathrm{m}{ }^{-2} \mathrm{~d}^{-1}\right)$. $\mathrm{NO}_{3}^{-}$appeared to be taken up by the sediment in both areas, although at rates not significantly different from zero (134 and $85 \mu \mathrm{mol} \mathrm{m} \mathrm{m}^{-2} \mathrm{~d}^{-1}$, respectively). The trend for higher uptake of DIN in the vegetated area may be related to microbial assimilation during degradation of nitrogen-poor tree litter. Nitrification rates, estimated from potential assays using oxygen penetration depth or measured as coupled nitrification-denitrification using a ${ }^{15} \mathrm{~N}$ isotope-pairing technique, were also very low (12 to $74 \mu \mathrm{mol} \mathrm{m} \mathrm{m}^{-2} \mathrm{~d}^{-1}$ ). Nitrification rates appeared higher and penetrated deeper in the vegetated than the unvegetated sediments as substantiated by higher concentrations of porewater $\mathrm{NO}_{3}{ }^{-}$. Denitrification rates were 3.5 times higher in the vegetated $\left(46 \mu \mathrm{mol} \mathrm{m} \mathrm{m}^{-2} \mathrm{~d}^{-1}\right)$ than the unvegetated sediments $\left(13 \mu \mathrm{mol} \mathrm{m} \mathrm{m}^{-2} \mathrm{~d}^{-1}\right.$. Since more than $90 \%$ of the $\mathrm{NO}_{3}^{-}$needed by denitrifiers originated from nitrification (coupled nitrification-denitrification), only 1 to $2 \%$ of the measured $\mathrm{NO}_{3}{ }^{-}$influx from the overlying water was consumed by denitrification. N fixation ( 284 to $390 \mu \mathrm{mol} \mathrm{m} \mathrm{m}^{-2} \mathrm{~d}^{-1}$ ) in the present mangrove sediments was estimated to account for about $10 \%$ of the net demand by primary producers. About half of the measured N fixation was due to fixation by sulfate reducing bacteria. The Ao Nam Bor mangrove forest was characterized by low concentrations, fluxes and rates of microbial transformations of DIN, suggesting a tight coupling between mineralization and assimilation processes. These nitrogen-poor seduments acted as sinks for nitrogen, due to microbial assimilation, and the presence of trees in the vegetated sediment was evident as a $50 \%$ higher net retention of DIN
\end{abstract}

KEY WORDS: Nitrogen cycling - Nitrification - Denitrification · $N$ fixation $\cdot$ Mangrove sediments

\section{INTRODUCTION}

Most intertidal coasts in the tropics are lined with mangrove forests (Por 1984). This widespread and productive ecosystem supports a unique assembly of animals and plants, and provides both an important linkage and buffer zone between land and ocean (Boto \& Wellington 1988, Morell \& Corredor 1993). However, since mangrove forests have been threatened by massive destruction during the last decades caused by

\footnotetext{
•E-mail: ebk@biology.ou.dk
}

charcoal logging and shrimp farming (Chansang et al. 1982, Hatcher et al. 1989, Macintosh 1996), there is an urgent need for detailed knowledge on the functional role of mangroves with respect to transport and transformations of nutrients.

The role of mangroves in the exchange of nutrients with coastal waters has been examined in an increasing number of studies in recent years (Boto \& Robertson 1990, Morell \& Corredor 1993). Although the general knowledge on mangrove nutrient dynamics has improved, the results are in a number of cases equivocal and sometimes conflicting, emphasizing the need 
for further studies in this important environment. A characteristic feature of these forests is very low levels of dissolved and particulate nutrients, and the forests generally appear to be $\mathrm{N}$ or P limited (Boto \& Wellington 1983, Alongi 1996). As a consequence, they possess a high capacity for retaining and recycling nutrients by several mechanisms that reduce export (Twilley et al. 1986). Wiebe (1989) also suggested that mangroves are a sink for nutrients, but warned that such generalization may be tentative. The extent to which mangroves exchange nutrients with adjacent waters depends upon a variety of factors, like geomorphology, tidal regime, climate and groundwater inputs (Alongi 1989, Alongi et al. 1992)

Studies on nitrogen cycling have mostly been concerned with the transport of dissolved and particulate forms between mangrove forest and the ocean, whereas the role of sediment processes has been addressed to a lesser extent (Boto \& Wellington 1988, Morell \& Corredor 1993, Rivera-Monroy et al. 1995a, b, Alongi 1996). The general features of mangrove sediments with respect to inorganic nitrogen are low concentrations, low uptake rates from the tidal water, and low rates of transformation processes. Many of the sediment investigations have focused on porewater pools and the exchange of dissolved nitrogen between the sediment and tidal waters (Alongi et al. 1993, Alongi 1996), while others have dealt with specific microbial nitrogen transformations, like nitrogen fixation and denitrification (Morell \& Corredor 1993, Nedwell et al. 1994, Rivera-Monroy et al. 1995b). However, there are to our knowledge only few mangrove studies in which an array of dissolved inorganic nitrogen transformations have been combined and examined simultaneously.

The purpose of this study was to determine the most important inorganic nitrogen transformations in the Ao Nam Bor mangrove forest in Thailand. Simultaneous measurements of $\mathrm{NH}_{4}{ }^{+}$and $\mathrm{NO}_{3}{ }^{-}$fluxes, nitrogen fixation, nitrification and denitrification were conducted in vegetated and non-vegetated mangrove sediments. The results are related to the pools particulate and dissolved nitrogen, and compared with the requirement of the dominating primary producers (trees and microphyrtobenthos).

\section{MATERIALS AND METHODS}

Study site. Samples were collected in the dry season during January 1992 in the $300 \mathrm{~m}$ wide mangrove forest Ao Nam Bor in Makham Bay, ca $4 \mathrm{~km}$ south of Phuket Town on the east coast of Phuket Island, Thailand. A detailed description of the study site is given by Kristensen et al. (1995). Two sampling stations in the
Iow- and mid-intertidal zone, respectively, were chosen for this study.

The mid-intertidal Stn 2 was located within the mangrove forest between 'prop' roots of Rhizophora apiculata ca $50 \mathrm{~m}$ from the seaward fringe. The sediment was heterogeneous and composed of grey-brown silt (90\% of particles $<63 \mu \mathrm{m})$ with an organic content of about $3 \% \mathrm{C}$ and $0.15 \% \mathrm{~N}$ (molar C:N ratio of about 24 ). Only the upper 4 to $6 \mathrm{~cm}$ was devoid of roots (silt zone); below was a deep root zone with peat-like appearance. The silt zone was never black and sulfidic, whereas scattered spots were apparent around dead roots in the root zone. This location was moderately affected by burrowing fauna (sesarmid crabs and sipunculids; Kristensen et al. 1994). The average diurnal water cover for January 1992 was $7.3 \mathrm{~h}$.

Stn 3 was located in the low-intertidal zone on the tidal flat ca $100 \mathrm{~m}$ outside the mangrove forest. The sediment appeared more sandy in the upper centimetres $(40 \%$ of particles $<63 \mu \mathrm{m})$ than at the other station. The sediment below was homogeneous and consisted of silty, non-sulfidic sand $(70 \%$ of particles $<63 \mu \mathrm{m})$ down to ca $30 \mathrm{~cm}$ depth followed by a zone of coarse coral sand. The organic content increased from about $0.5 \% \mathrm{C}$ and $0.02 \% \mathrm{~N}$ in the upper $5 \mathrm{~cm}$ to $1.0 \% \mathrm{C}$ and $0.04 \% \mathrm{~N}$ below $10 \mathrm{~cm}$ depth (molar $\mathrm{C}: \mathrm{N}$ ratio of about 30 ). The dominating burrowing animals at this station were ocypodid crabs, mudskippers and small $(1$ to $3 \mathrm{~cm}$ long) polychaete worms of unknown species (Kristensen et al. 1994). The average diurnal water cover for January 1992 was $9.6 \mathrm{~h}$. Salinity and water temperature during sampling were 33 to $35 \%$ and 28 to $33^{\circ} \mathrm{C}$ at both stations.

Fluxes and porewater profiles. For determination of dissolved inorganic nitrogen (DIN $=\mathrm{NH}_{4}{ }^{+}, \mathrm{NO}_{2}{ }^{-}$and $\mathrm{NO}_{3}{ }^{-}$) flux across the sediment-water interface during inundation, 4 sediment cores $(8 \mathrm{~cm}$ in diameter and $13 \mathrm{~cm}$ deep) were sampled per station during low tide In the laboratory, the still air-exposed, but darkened cores were pre-incubated at in situ temperature $\left(29^{\circ} \mathrm{C}\right)$. After 1 to $4 \mathrm{~h}$, seawater was carefully added resulting in a water column height of $9 \mathrm{~cm}$. Flux rates of DIN were obtained by standard closed-core incubations of 2 to 7 h duration in darkness according to Kristensen et al. (1991). Water samples for DIN analysis were taken at the start and end of incubation, assuming linear concentration change with time. This was occasionally verified by sequential samplings (data not shown). The samples were GF/C filtered and stored frozen in polyethylene vials until analysis using standard autoanalyzer methods of Solorzano (1969) for $\mathrm{NH}_{4}{ }^{+}$and Armstrong et al. (1967) for $\mathrm{NO}_{2}{ }^{-}$and $\mathrm{NO}_{3}{ }^{-}$. As $\mathrm{NO}_{2}^{-}$concentrations were very low and constant, this compound is included here in the presented $\mathrm{NO}_{3}$ data. 
Three sediment cores $(5 \mathrm{~cm}$ in diameter and $30 \mathrm{~cm}$ deep) for porewater extraction were sampled at each of the 2 stations. Within 2 h of sampling, the cores were sectioned into 1 and $2 \mathrm{~cm}$ segments, and porewater was extracted by centrifugation for 5 to $10 \mathrm{~min}$ at $2000 \mathrm{rpm}(250 \times \mathrm{g})$. The supernatant porewater was GF/C filtered and stored frozen for later DIN analysis as mentioned above.

Potential nitrification. Potential nitrification was determined in aerobic sediment slurries as the accumulation of $\mathrm{NO}_{2}^{-}$after addition of chlorate. Immediately after sampling during low tide, 2 sediment cores (5 $\mathrm{cm}$ diameter, $20 \mathrm{~cm}$ deep) were subcored to $15 \mathrm{~mm}$ depth by $5 \mathrm{ml}$ cut-off syringes. The subcores were extruded and sectioned into $0-2,2-4,4-7,7-10$ and $10-15 \mathrm{~mm}$ depth intervals. Duplicate samples of about $0.3 \mathrm{~g}$ wet weight from each section were transferred to $30 \mathrm{ml}$ serum bottles containing $10 \mathrm{ml}$ of seawater enriched with $\mathrm{NH}_{4} \mathrm{Cl}, \mathrm{KH}_{2} \mathrm{PO}_{4}$ and $\mathrm{NaClO}_{3}$ to concentrations of $500 \mu \mathrm{M}, 50 \mu \mathrm{M}$ and $10 \mathrm{mM}$, respectively. The addition of chlorate $\left(\mathrm{NaClO}_{3}\right)$ inhibits the oxidation of $\mathrm{NO}_{2}^{-}$, which will accumulate in the slurry and can easily be analyzed (Belser \& Mays 1980). The serum bottles were incubated aerobically in the dark at in situ temperature $\left(29^{\circ} \mathrm{C}\right)$ on a shaking table. After $0,3,6$ and $10 \mathrm{~h}$, subsamples of $1.5 \mathrm{ml}$ were taken and centrifuged at $3000 \mathrm{rpm}(375 \times \mathrm{g})$ for $5 \mathrm{~min}$. The supernatant was stored frozen until spectrophotometric analysis according to Strickland \& Parsons (1972). Potential nitrification was determined from the slope of $\mathrm{NO}_{2}{ }^{-}$increase with time and related to sediment volume.

Denitrification. A modification of the ${ }^{15} \mathrm{~N}$ isotopepairing technique of Nielsen (1992) was used for measurement of in situ denitrification rates. A total of 7 to 11 sediment cores $(3.6 \mathrm{~cm}$ in diameter and $5 \mathrm{~cm}$ deep) from each station were taken at low tide and transported to the laboratory for further processing within an hour. In the laboratory, cores were carefully supplied with air-saturated seawater (from the sampling site) to a depth of $5 \mathrm{~cm}$, and submerged in a darkened tank containing about $30 \mathrm{l}$ of the same water. Cores were equipped with magnetic stirring bars receiving momentum from a rotating external magnet (60 rpm). The cores were then allowed to equilibrate uncapped for 3 to $4 \mathrm{~h}$ at in situ temperature $\left(29^{\circ} \mathrm{C}\right)$.

The denitrification assay was initiated by adding ${ }^{15} \mathrm{NO}_{3}^{-}(99 \%)$ to the tank water at a final concentration of $30 \mu \mathrm{M}$. The ambient ${ }^{15} \mathrm{~N}$ level was assumed negligible. The uncapped cores were pre-incubated for 12 to $14 \mathrm{~h}$ with ${ }^{15} \mathrm{NO}_{3}{ }^{-}$in order to obtain a near steady state (>90\%) efflux of ${ }^{29} \mathrm{~N}_{2}$ and ${ }^{30} \mathrm{~N}_{2}$ (Nielsen 1992). The incubation was initiated by capping the cores with inverted glass petri dishes. Preliminary experiments had shown that this was sufficient to prevent exchange of dissolved gases. After incubation for 1 to $4 \mathrm{~h}$ (tests showed that $\mathrm{O}_{2}$ never decreased below $75 \%$ of air saturation), cores were removed from the incubation tank, uncapped and $45 \mathrm{ml}$ of water (final sample) was taken immediately from each core using a $50 \mathrm{ml}$ plastic syringe. Care was taken not to introduce air bubbles into the syringe. Triplicate water samples were taken from the tank water for determination of initial (start sample) DIN concentrations and isotopic composition as mentioned above.

After placing a hypodermic needle on the tip of each syringe, $5 \mathrm{ml}$ of the sample was discarded and $5 \mathrm{ml}$ of pure $\mathrm{O}_{2}$ was slowly sucked into the syringe, which was stoppered by a rubber stopper. Then the syringe was shaken vigorously for 2 min to equilibrate dissolved $\mathrm{N}_{2}$ with the headspace, and a $3 \mathrm{ml}$ gas sample was withdrawn into a pre-evacuated Venoject tube (Terumo Corp., Belgium) immediately after removing the rubber stopper. The remaining water sample was frozen for later DIN analysis as previously described.

Nitrogen gas isotopic composition was analyzed by injecting $0.2 \mathrm{ml}$ of the Venoject subsamples into a gas chromatograph in line with a Sira Series II isotope ratio mass spectrometer. Denitrification rates were calculated from ${ }^{29} \mathrm{~N}_{2}$ and ${ }^{30} \mathrm{~N}_{2}$ production rates during incubations as described by Nielsen (1992).

Nitrogen fixation. Sediment nitrogen fixation was determined by a modified version of the classic acetylene reduction technique (Stewart et al. 1967. Capone 1988). Sediment cores similar to those used for porewater extraction (5 cm i.d.) were sectioned into $1 \mathrm{~cm}$ slices and the depth intervals $0-1,5-6$ and $14-15 \mathrm{~cm}$ (Stn 2) or 19-20 cm (Stn 3) were used for the N-fixation assay. Triplicate subsamples of about $3 \mathrm{~g}$ sediment from each depth interval were transferred to $30 \mathrm{ml}$ serum bottles together with $2 \mathrm{ml}$ of deoxygenated seawater ( $\mathrm{N}_{2}$ purged). Although all visible Rhizophora apiculata roots were removed from Stn 2 subsamples, small roots may still have been present. Subsequently, the bottles were flushed with $\mathrm{N}_{2}$ for a few minutes before being sealed with butyl stoppers and placed on a shaking table in the dark at in situ temperature $\left(29^{\circ} \mathrm{C}\right)$. After a few minutes of equilibration, $3 \mathrm{ml}$ of the gas phase was evacuated and replaced with $3 \mathrm{ml}$ of $\mathrm{C}_{2} \mathrm{H}_{2}$. Sampling was initiated about 20 min later and repeated 5 times at 10 to 15 min intervals. During sampling, $0.5 \mathrm{ml}$ gas was withdrawn using a $1 \mathrm{ml}$ syringe (dispo glass) and transferred in triplicates to Venoject tubes. The Venojects had been previously opened, cleaned and sealed with stoppers that did not release hydrocarbons. A vacuum was created in the Venojects immediately prior to injecting samples. Samples were assayed after bringing the Venojects to atmospheric pressure with air and adding $0.5 \mathrm{ml}$ of an ammoniacal silver nitrate solution to precipitate 
acetylene as silver acetylide (David et al. 1980). Subsamples of $0.5 \mathrm{ml}$ from the Venoject headspace were analyzed on a Shimadzu GC-14A equipped with a Poropak $Q$ column in series with a capillary column containing DB-1 and detected by FID. $N$ fixation was estimated based on the theoretical 3:1 ratio between ethylene produced and $\mathrm{N}_{2}$ fixed (e.g. Capone 1988), since no calibration was done here against a direct (e.g. ${ }^{15} \mathrm{~N}$ ) method.

In order to determine the impact of a surplus inorganic nitrogen source and the role of sulfate reducing bacteria on $\mathrm{N}$ fixation in the sediment, 2 parallel series from the 5 to $6 \mathrm{~cm}$ depth interval were added either $\mathrm{NH}_{4}{ }^{+}$to a concentration of $2 \mathrm{mM}$ or the specific inhibitor of bacterial sulfate reduction, $\mathrm{Na}_{2} \mathrm{MoO}_{4}$, to a concentration of $20 \mathrm{mM}$. The sampling and analysis were done as mentioned above for unamended sediment.

The association of $\mathrm{N}$-fixing bacteria with roots of mangrove trees was determined by adding 50 to $100 \mu \mathrm{g}$ live roots to the incubation bottles instead of sediment. Fine and live roots from the tree Rhizophora apiculata were carefully removed from the sediment and rinsed in seawater to remove adhered particles before being transferred to the incubation bottles. The sampling and analysis were done as mentioned above for sediment incubations.

\section{RESULTS}

\section{Sediment-water fluxes}

The dark flux of dissolved inorganic nitrogen $\left(\mathrm{NH}_{4}{ }^{+}\right.$ and $\mathrm{NO}_{3}{ }^{-}$) across the sediment-water interface was low and mostly directed into the sediment (Table 1). At
Table 1. Dark flux (mean. $\pm \mathrm{SD}, \mathrm{n}=4)$ of $\mathrm{NH}_{4}{ }^{+}\left(J_{\mathrm{NH}_{4}}\right)$ and $\mathrm{NO}_{3}{ }^{-}$ $\left(\mathrm{NO}_{3}\right)$ across the sediment-water interface at Stns 2 and 3 in the Ao Nam Bor mangrove forest. Negative values indicate fluxes directed into the sediment. The overlying water concentration is shown for comparison

\begin{tabular}{|ccccc|}
\hline & $\begin{array}{c}J_{\mathrm{NH}_{4}} \\
\left(\mu \mathrm{mol} \mathrm{m} \mathrm{m}^{-2} \mathrm{~d}^{-1}\right)\end{array}$ & $\begin{array}{c}{\left[\mathrm{NH}_{4}{ }^{+}\right]} \\
(\mu \mathrm{M})\end{array}$ & $\begin{array}{c}J_{\mathrm{NO}_{3}} \\
\left(\mu \mathrm{mol} \mathrm{m}^{-2} \mathrm{~d}^{-1}\right)\end{array}$ & $\begin{array}{c}{\left[\mathrm{NO}_{3}{ }^{-}\right]} \\
(\mu \mathrm{M})\end{array}$ \\
\hline Stn 2 & $-204 \pm 429$ & 1.2 & $-134 \pm 136$ & 0.69 \\
Stn 3 & $80 \pm 371$ & 4.7 & $-85 \pm 292$ & 0.63 \\
\hline
\end{tabular}

Stn 2, within the mangrove forest, both $\mathrm{NH}_{4}{ }^{+}$and $\mathrm{NO}_{3}{ }^{-}$ tended to be taken up by the sediment from low concentrations in the overlying water. The situation at Stn 3 was similar for $\mathrm{NO}_{3}{ }^{-}$, but $\mathrm{NH}_{4}{ }^{+}$appeared to be released here despite a 4 times higher concentration in the overlying water. It should be noled, however, that none of the average fluxes presented in Table 1 were significantly different from 0 ( $t$-test, $\mathrm{p}>0.05)$ due to high inter-core variability.

\section{Porewater profiles}

The 2 examined stations exhibited different depth profiles of dissolved $\mathrm{NH}_{4}{ }^{+}$and $\mathrm{NO}_{3}{ }^{-}$in the sediment (Fig. 1). Profiles of $\mathrm{NH}_{4}{ }^{+}$showed much higher concentrations at the non-vegetated Stn 3 than at the forested Stn 2. At the former, the concentration of $\mathrm{NH}_{4}{ }^{+}$ increased to a level of 200 to $300 \mu \mathrm{M}$ at $5 \mathrm{~cm}$ depth, remained almost constant down to about $12 \mathrm{~cm}$, and increased again below this depth to $400-500 \mu \mathrm{M}$ at $27 \mathrm{~cm}$. $\mathrm{NH}_{4}{ }^{+}$remained at a low level between 10 and $50 \mu \mathrm{M}$ at all depths down to $27 \mathrm{~cm}$ at Stn 2, with a small peak around 5 to $7 \mathrm{~cm}$. The porewater concentration of $\mathrm{NO}_{3}{ }^{-}$showed the opposite pattern, with the highest level at Stn 2. However, the concentrations were generally very low and with high inter-core variability. $\mathrm{NO}_{3}{ }^{-}$remained at a level around $2 \mu \mathrm{M}$ in the entire depth interval at Stn 2, whereas this level was approached only within the upper $3 \mathrm{~cm}$ at Stn $3 . \mathrm{NO}_{3}{ }^{-}$was hardly detectable below $5 \mathrm{~cm}$ depth at the latter station.

\section{Potential nitrification}

Although rates of potential nitrification appeared higher at Stn 2 than Stn 3 (Fig. 2), the difference was not significant at any depth ( $t$-test, $p>0.05$ ). Rates varied between 20 and $60 \mathrm{nmol} \mathrm{cm}^{-3} \mathrm{~d}^{-1}$ within the upper
Fig. 1. Porewater profiles of $\mathrm{NH}_{4}{ }^{+}$and $\mathrm{NO}_{3}{ }^{-}$in the upper $30 \mathrm{~cm}$ of vegetated (Stn 2) and non-vegetated (Stn 3) sediments from the Ao Nam Bor mangrove forest. Concentrations are given as mean $\pm \mathrm{SD}(\mathrm{n}=3)$ 
Table 2. Area-specific nitrogen transformations ( $\mu$ mol $\mathrm{N} \mathrm{m}^{-2}$ $\mathrm{d}^{-1}$, mean $\pm \mathrm{SD}$ of $n$ measurements) at Stns 2 and 3 in sediment of the Ao Nam Bor mangrove forest. (1) Estimated nitrification based on potential nitrification measurements and the oxygen penetration depth; (2) estimated nitrification based on the degree of coupling between nitrification and denitrification found by the isotope-pairing technique; (3) measured denitrification based on the isotope-pairing technique; and (4) depth integrated $(0$ to $15 \mathrm{~cm}) \mathrm{N}$ fixation based on slurry incubations

\begin{tabular}{|lcccc|}
\hline & Stn 2 & $n$ & $\operatorname{Stn} 3$ & $\mathrm{n}$ \\
\hline (1) Nitrification (pot) & $59 \pm 51$ & 2 & $74 \pm 10$ & 2 \\
(2) Nitrification ( $\left.{ }^{15} \mathrm{~N}\right)$ & $43 \pm 9$ & 4 & $12 \pm 3$ & 3 \\
(3) Denitrification & $46 \pm 9$ & 4 & $13 \pm 3$ & 3 \\
(4) N fixation (0 to $15 \mathrm{~cm}$ ) & $284 \pm 10$ & 3 & $390 \pm 21$ & 3 \\
\hline
\end{tabular}

$13 \mathrm{~mm}$ of the sediment column at the former station. However, none of the variations with depth were significantly different due to high inter-core variability. Stn 3 was different, showing gradually, but significantly ( $p<0.05$ ), decreasing rates (from 40 to $16 \mathrm{nmol}$ $\mathrm{cm}^{-3} \mathrm{~d}^{-1}$ ) with depth from the surface down to $13 \mathrm{~mm}$. The low variability in potential nitrification substantiates the relatively homogeneous composition of the upper sediment layers at this station.

Since nitrification is an aerobic process, the depth of oxygen penetration at the sediment surface is an indicator of the depth of the nitrification zone, and can be used to provide a maximum estimate of the surficial nitrification rate (Hansen et al. 1981). Oxygen penetration depths in darkness of $1.65 \mathrm{~mm}$ at Stn 2 and $1.9 \mathrm{~mm}$ at Stn 3 have previously been recorded in the Ao Nam Bor mangrove during the dry season (Kristensen et al. 1994). Based on these oxygen data and the potential nitrification results presented here, the maximum area-specific nitrification rates are estimated to be 59 and $74 \mu \mathrm{mol} \mathrm{m} \mathrm{m}^{-2} \mathrm{~d}^{-1}$ at Stns 2 and 3, respectively (Table 2).

\section{Denitrification}

The addition of $30 \mu \mathrm{M}^{15} \mathrm{NO}_{3}{ }^{-}$to the overlying water in cores used for the denitrification assay increased the total $\mathrm{NO}_{3}{ }^{-}$uptake by a factor of 7 to $10(750 \pm 300 \mu \mathrm{mol}$ $\mathrm{m}^{-2} \mathrm{~d}^{-1}$ at $\operatorname{Stn} 2$ and $1000 \pm 390 \mu \mathrm{mol} \mathrm{m}^{-2}$ $\mathrm{d}^{-1}$ at Stn 3) compared to unamended cores (Table 1). Anyway, based on the isotopepairing theory of Nielsen (1992), the formation of single-labelled $\left({ }^{14} \mathrm{~N}^{15} \mathrm{~N}\right)$ and double-labelled $\left({ }^{15} \mathrm{~N}^{15} \mathrm{~N}\right)$ dinitrogen can be used to estimate total denitrification of the naturally occurring ${ }^{14} \mathrm{NO}_{3}{ }^{-}$. By this method it is also possible to differentiate between denitrification of $\mathrm{NO}_{3}{ }^{-}$diffusing from the overlying water (uncoupled denitrification) and $\mathrm{NO}_{3}{ }^{-}$from nitrification within the sediment (coupled denitrification).

Total area-specific denitrification at the 2 stations in the Ao Nam Bor mangrove was low (Table 2). The rates measured at Stn $2\left(46 \mu \mathrm{mol} \mathrm{m} \mathrm{m}^{-2} \mathrm{~d}^{-1}\right)$ were almost 4 times higher than at Stn $3\left(13 \mu \mathrm{mol} \mathrm{m}^{-2} \mathrm{~d}^{-1}\right)$. Coupled denitrification accounted for most of the total rates, 90 to $97 \%$ at Stn 2 and 87 to $94 \%$ at Stn 3, due to the low $\mathrm{NO}_{3}{ }^{-}$concentration in the overlying water. This indicates an area-specific coupled nitrification rate of 43 and $12 \mu \mathrm{mol} \mathrm{m} \mathrm{m}^{-2} \mathrm{~d}^{-1}$ at Stns 2 and 3, respectively.

\section{Nitrogen fixation}

Fixation of atmospheric dinitrogen was relatively low in the upper silt zone at Stn 2 (1 to $2 \mathrm{nmol} \mathrm{N} \mathrm{cm}{ }^{-3}$ $\mathrm{d}^{-1}$ ), but attained rates of twice this level in the underlying root zone $\left(3 \mathrm{nmol} \mathrm{N} \mathrm{cm}^{-3} \mathrm{~d}^{-1}\right.$ at 14 to $15 \mathrm{~cm}$ depth; Fig. 3). The difference was probably related to a high $\mathrm{N}$ fixation associated with live roots of Rhizophora apiculata $\left[262 \pm 100 \mathrm{nmol}(\mathrm{g} \mathrm{ww})^{-1} \mathrm{~d}^{-1}\right]$. N fixation at Stn 3 was relatively constant with depth down to $20 \mathrm{~cm}$ at a level about 50 to $100 \%$ higher than in the silt zone at Stn 2 . The depth-integrated rates were about $40 \%$ higher at Stn 3 than Stn 2 (Table 2).

There was no apparent inhibitory effect of $\mathrm{NH}_{4}{ }^{+}$in surplus on rates of $\mathrm{N}$ fixation in the depth interval 5 to $6 \mathrm{~cm}$ at either Stn 2 or Stn 3 (Fig. 3). However, additions of $\mathrm{Na}_{2} \mathrm{MoO}_{4}$ to the same depth interval reduced $\mathrm{N}$ fixation to $70 \%$ at $\operatorname{Stn} 2$ and $40 \%$ at $\operatorname{Stn} 3$ of the rates found in uninhibited slurries (Fig. 3), implying that sul-

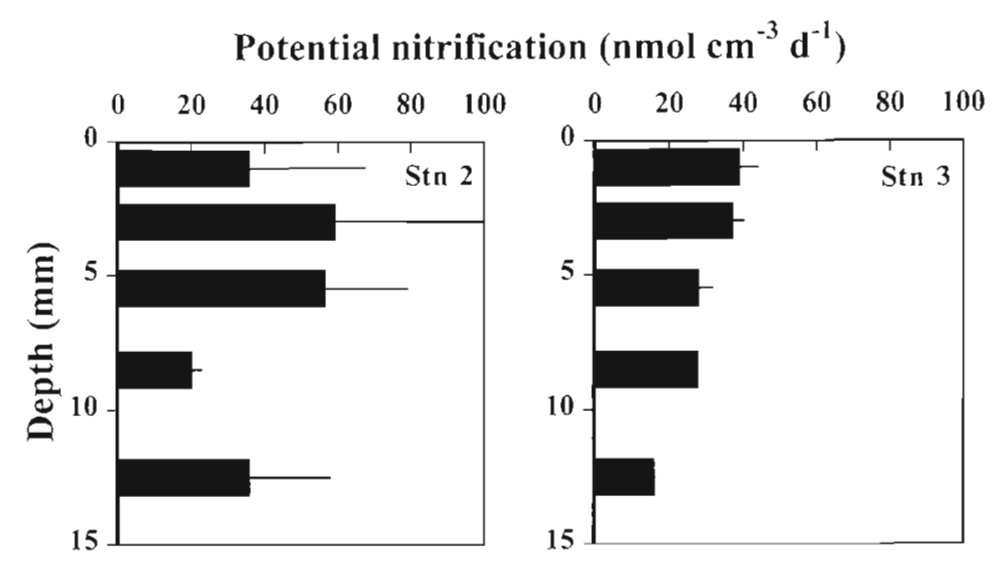

Fig. 2. Vertical profiles of potential nitrification in the upper $15 \mathrm{~cm}$ of vegetated (Stn 2) and non-vegetated (Stn 3) sediments from the Ao Nam Bor mangrove forest. Rates are given as mean $\pm S D(n=3)$ 


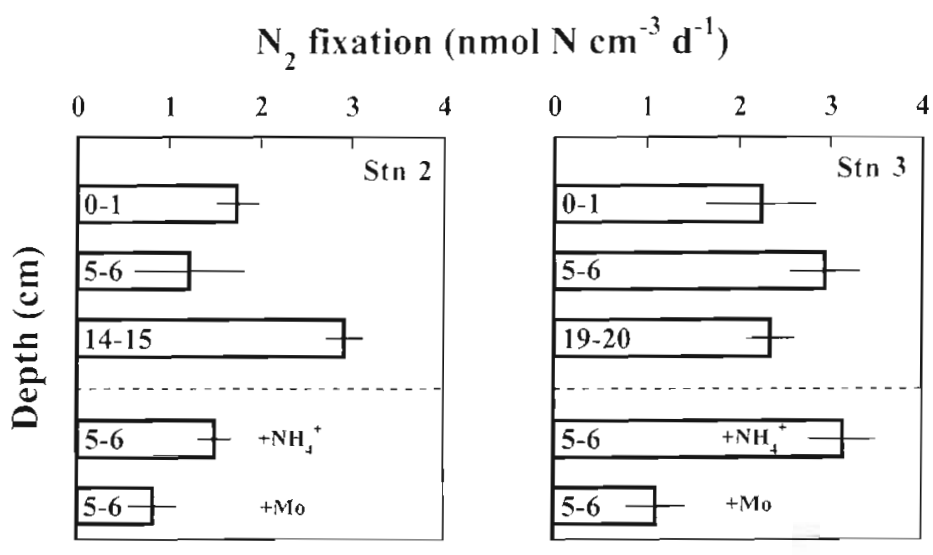

Fig. 3. Vertical profiles of $\mathrm{N}$ fixation determined by the acetylene reduction technique. Rates are given for 3 depth intervals between 0 and $15 \mathrm{~cm}$ in the vegetated (Stn 2) sediment and between 0 and $20 \mathrm{~cm}$ in the non-vegetated (Stn 3) sediment (numbers within bars indicate depth intervals). Rates presented below the dashed line are repetitive measurements from the intermediate depth interval $(5$ to $6 \mathrm{~cm}$ ) after addition of either $2 \mathrm{mM} \mathrm{NH}_{4}{ }^{+}$or $20 \mathrm{mM} \mathrm{Na}_{2} \mathrm{MoO}_{4}$. All rates are given as mean $\pm \mathrm{SD}(\mathrm{n}=3)$

fate reducing bacteria were responsible for a significant portion of the observed $\mathrm{N}$ fixation.

\section{DISCUSSION}

Although this study presents a one-time 'snapshot' of inorganic nitrogen cycling in darkened and inundated sediments of the Ao Nam Bor mangrove forest, the results seem representative for many tropical mangrove environments. The low concentrations (Fig. 1), fluxes (Table 1) and rates of microbial transformations (Table 2) of dissolved inorganic nitrogen found at Ao Nam Bor support the notion that tropical mangrove ecosystems are inherently nutrient-poor compared to other intertidal systems (e.g. saltmarshes) and that they act as sinks of inorganic nitrogen (Boto \& Wellington 1988, Alongi et al. 1992, Morell \& Corredor 1993, Rivera-Monroy et al. 1995b, Alongi 1996, RiveraMonroy \& Twilley 1996).

The somewhat lower concentrations and higher inport (although not significantly) of nutrients in darkened Rhizophora apiculata vegetated than in nonvegetated sediment at Ao Nam Bor suggest a mangrove tree related demand. Such a pattern was also noted by Alongi (1996) for Australian mangrove forests. It is tempting to relate the apparent reversal in $\mathrm{NH}_{4}{ }^{*}$ flux pattern between the 2 study areas (Table 1) together with an order of magnitude lower concentration of this solute in the porewater at the vegetated site (Fig. 1) to uptake by tree roots. However, as $R$. apiculata generally prefers $\mathrm{NO}_{3}^{-}$(Boto et al. 1985), a sub- stantial part of the high $\mathrm{NH}_{4}{ }^{+}$demand must instead be assigned to assimilation during microbial degradation of nutrient-poor tree tissues (litter, dead roots, twigs and trunks) in the sediment (Alongi 1996, Rivera-Monroy \& Twilley 1996).

Bacteria generally need substrates with an elemental C:N ratio below 10 for maintenance and growth (Fenchel \& Blackburn 1979), so mangrove litter and other tree materials with $C: N$ ratios of 100 or even more (Kristensen 1990) are a highly insufficient substrate. Accordingly, the cycling of inorganic nitrogen must be rapid, efficient (i.e. tight), but not sufficient to support bacterial growth in mangrove sediments. Unfortunately, no measures of $\mathrm{NH}_{4}{ }^{+}$turnover are available from the present study, but a rapid turnover of 1.5 to $9 \mathrm{~d}^{-1}$ in the upper 4 to $8 \mathrm{~cm}$ of the sediment has been reported from other tropical mangrove forests (Blackburn et al. 1987, Nedwell et al. 1994). The microbial demand for nitrogen in the vegetated sediment must be particularly high at the sediment-water interface since the porewater profile of $\mathrm{NH}_{4}{ }^{+}$, in contrast to the measured fluxes, indicates that there should be a considerable release from the sediment during inundation. Several flux studies in mangrove sediments have suggested that dissolved inorganic nitrogen in tidal waters is actually trapped in the upper few centimeters of the sediment due to a tight coupling between microbial mineralization and assimilation (Stanley et al. 1987, Alongi 1988, 1996, Boto \& Wellington 1988, RiveraMonroy et al. 1995b). In the non-vegetated area at Ao Nam Bor, where no litter accumulation occurs and porewater $\mathrm{NH}_{4}{ }^{+}$increases to relatively high concentrations, the assimilatory demand by benthic microalgae may contribute to a lower $\mathrm{NH}_{4}{ }^{+}$release than expected (Kristensen 1993), even when measured in darkness as here (Rysgaard et al. 1993).

The measured fluxes and porewater concentrations of $\mathrm{NH}_{4}{ }^{+}$and $\mathrm{NO}_{3}{ }^{*}$ in $\mathrm{Ao}$ Nam Bor sediments are similar to other tropical mangrove sediments (Rivera-Monroy et al. 1995b, Alongi 1996), but lower than in most coastal marine sediments (Nixon 1981, Kristensen 1988). The gradients of $\mathrm{NO}_{3}{ }^{-}$in the upper $0.5 \mathrm{~cm}$ of the sediment (Fig. 1) and measured influx (Table 1) of this compound are, as was the case for $\mathrm{NH}_{4}{ }^{+}$in the vegetated sediment, contradictory. A similar $\mathrm{NO}_{3}{ }^{-}$pattern has been observed in other intertidal sediments (Henriksen et al. 1981, Kristensen et al. 1988, Alongi et al. 1993) and may be explained by depth dependent changes in the balance between nitrification and $\mathrm{NO}_{3}{ }^{-}$uptake by assimilation (autotrophic and heterotrophic), dissimilatory reduction to $\mathrm{NH}_{4}{ }^{+}$(nitrate am- 
monification) and $\mathrm{N}_{2}$ (denitrification) in the surface layers.

\section{Nitrification}

The presence of $\mathrm{NO}_{3}$ in the porewater down to at least $30 \mathrm{~cm}$ depth in the vegetated sediment (Fig. 1) indicates active nitrification below the oxic surface layer. Active subsurface nitrification associated with roots of aquatic macrophytes has been observed in a number of cases (Reddy et al. 1989, Caffrey \& Kemp 1992) and is due to downward translocation and release of $\mathrm{O}_{2}$ by roots. The $\mathrm{NO}_{3}{ }^{-}$profile in the non-vegetated sediment, on the other hand, is typical for marine sediments where nitrification is restricted to the upper oxic surface layer (Henriksen \& Kemp 1988). The depth pattern of potential nitrification parallels the observed $\mathrm{NO}_{3}{ }^{-}$profiles (Fig. 2). The generally higher rates with depth at the vegetated site, reflecting a higher population density or enzyme activity of nitrifying bacteria, suggests that nitrifiers are subject to superior (more oxic) conditions here compared with the non-vegetated sediment. However, numerous studies have confirmed that potential nitrification in sediments is only an indicator of nitrifiers being present, and not a measure of actual nitrification (e.g. Henriksen \& Kemp 1988). The potential nitrification rates found here are in the low range of previously published rates from tropical mangrove sediments (0 to $300 \mathrm{nmol} \mathrm{cm} \mathrm{cm}^{-3} \mathrm{~d}^{-1}$; Iizumi 1986, Shaiful et al. 1986), and more than an order of magnitude lower than usually found in temperate coastal sediments (Henriksen \& Kemp 1988).

When maximum area-specific nitrification rates at Ao Nam Bor were calculated from potential rates and oxygen penetration depths, almost similar rates were obtained in both sediment types (Table 2). These estimates are, however, uncertain due to a number of problems. First, nitrification in the oxic zone may be limited by ammonium availability compared to the potential assay where $\mathrm{NH}_{4}{ }^{+}$is provided in excess. The concentrations of $\mathrm{NH}_{4}{ }^{+}$in the surface sediment at Ao Nam Bor $(20$ and $60 \mu \mathrm{M}$ in the upper $0.5 \mathrm{~cm}$ at Stns 2 and 3 , respectively) are low compared with the halfsaturation constant of ammonium oxidizers in culture $\left(K_{\mathrm{m}}=50\right.$ to $\left.70 \mu \mathrm{M}\right)$, although natural samples have shown considerably lower kinetic constants (Kaplan 1983). Second, mixing and stirring of slurries often enhances microbial processes significantly compared to undisturbed sediment (Jørgensen 1978, Burdige 1989), due in part to the breakdown of diffusive barriers in the sediment matrix. Third, the use of oxygen penetration depths in darkened sediments for determination of diurnal rates may underestimate the nitrifica- tion rates during light exposure when microphytobenthic photosynthesis expands the oxic zone (Rysgaard et al. 1995).

The similarity between nitrification rates coupled to denitrification by the non-destructive ${ }^{15} \mathrm{~N}$ technique and those estimated from potential rates in the vegetated sediment (Table 2) suggests that the various problems associated with the latter technique may in our case have balanced out and probably by chance resulted in similar areal rates. Coupled nitrification determined by ${ }^{15} \mathrm{~N}$ should represent all nitrification in the sediment when no loss of $\mathrm{NO}_{3}{ }^{-}$occurs as indicated by the measured influx from the overlying water (Nielsen 1992). However, if a high coupled nitrification-assimilation occurred in the surface layers as suggested from profiles and fluxes of $\mathrm{NO}_{3}^{-}$(as mentioned previously), then nitrification determined from ${ }^{15} \mathrm{~N}$ is underestimated concurrently. The slurry-estimated areal rate of nitrification at the non-vegetated sediment was 5 to 6 times higher than rates determined from ${ }^{15} \mathrm{~N}$, probably due to the uncertainties mentioned above. Based on the coupled nitrification data from the isotope-pairing technique, the vegetated area supported a 3.5 times higher area-specific nitrification rate than the non-vegetated area. Since both techniques for determination of areal nitrification rates only include the oxic few mm thick surface layer of the sediment, the present results from vegetated sediment are probably underestimates due to translocation and release of $\mathrm{O}_{2}$ to subsurface layers where nitrification may occur.

\section{Denitrification}

In accordance with the low $\mathrm{NO}_{3}{ }^{-}$levels, denitrification rates in the Ao Nam Bor mangrove forest were very low (Table 2). There are few other studies available on denitrification in mangrove sediments, and those of Rivera-Monroy et al. (1995b) and Rivera-Monroy \& Twilley (1996), using a ${ }^{15} \mathrm{~N}$ enrichment technique, confirm the low rates. Actually, denitrification was barely detectable at in situ $\mathrm{NO}_{3}{ }^{-}$concentrations in these studies, and only ranged between 40 and $200 \mu \mathrm{mol} \mathrm{m} \mathrm{m}^{-2} \mathrm{~d}^{-1}$ in sediments amended with up to $200 \mathrm{\mu M} \mathrm{NO}_{3}{ }^{-}$. The 3.5 times higher area-specific denitrification rate in the vegetated compared to the nonvegetated sediment at Ao Nam Bor was caused by the higher nitrification rate and thus higher porewater $\mathrm{NO}_{3}{ }^{-}$concentrations. Mangrove forests receiving large $\mathrm{NO}_{3}{ }^{-}$discharges from sewage treatments plants show relatively high denitrification rates (using mass balance or $\mathrm{C}_{2} \mathrm{H}_{2}$ blockage techniques) at a level 1 to 2 orders of magnitude higher than in the present study (Nedwell 1975, Corredor \& Morell 1994). The denitrifi- 
cation rates in these polluted mangrove forest are, however, comparable to rates (using the ${ }^{15} \mathrm{~N}$ isotopepairing technique) obtained from unpolluted and relatively $\mathrm{NO}_{3}{ }^{-}$poor coastal sediments in temperate areas (e.g. Rysgaard et al. 1995), substantiating that the capacity for denitrification in mangrove sediments is generally low and not only related to $\mathrm{NO}_{3}{ }^{-}$availability.

Since more than $90 \%$ of the $\mathrm{NO}_{3}{ }^{-}$needed by denitrifiers in the present study originated from nitrification, only 1 to $2 \%$ of the $\mathrm{NO}_{3}{ }^{-}$influx from the overlying water was consumed by denitrification. This is in contrast to the results of Rivera-Monroy \& Twilley (1996), where no coupled nitrification-denitrification was detectable in a mangrove forest from Mexico. Anyway, the present data largely support their final conclusion that mangrove sediments are sinks for $\mathrm{NO}_{3}$ from tidal waters due to assimilation by sediment bacteria and tree roots, but not by denitrification. The possibility of $\mathrm{NO}_{3}{ }^{-}$removal by reduction to $\mathrm{NH}_{4}{ }^{+}$, as frequently observed in other coastal sediments (Koike \& Sørensen 1988), was not addressed in the present study, but Rivera-Monroy \& Twilley (1996) found that generally less than $2 \%$ of added ${ }^{15} \mathrm{NO}_{3}^{-}$(25 to $200 \mu \mathrm{M}$ ) was recovered as ${ }^{15} \mathrm{NH}_{4}{ }^{+}$in a Mexican mangrove sediment.

\section{$\mathbf{N}$ fixation}

As in the case of the potential nitrification assay, the slurry estimated rates of $\mathrm{N}$ fixation (Table 2) are subject to uncertainties. First, the slurry technique as used here may overestimate rates measured by nondestructive whole-core techniques by up to a factor of 40 (Welsh et al. 1996). Slurrying may release labile substrates from both roots and the sediment matrix as well as alleviating the natural diffusion limitation in sediments. Second, the theoretical 3:1 ratio used to transform acetylene reduction rates into $\mathrm{N}$ fixation is probably too low. While the theoretical ratio of $3: 1$ appears reasonable for pure cultures of bacteria (Stewart et al. 1967), measured ratios in marine sediments generally range between $2: 1$ and 10:1, with extreme values as high as 100:1 (Seitzinger \& Garber 1987, Howarth et al. 1988). Third, simple depth integration to obtain area-specific rates of sediment $\mathrm{N}$ fixation in vegetated areas may result in a considerable underestimate. A number of studies have demonstrated that $\mathrm{N}$ fixation in the rhizosphere of sediments vegetated by a variety of rooted plants can be very high due to supply of oxygen and labile carbon (Capone 1988, O'Donohue et al. 1991, Welsh et al. 1996). This is substantiated in the present study by root associated rates up to 300 times higher by weight than sediment rates. Furthermore, structures such as cyanobacterial mats, decomposing logs and algal covered prop roots may con- tribute considerably to $\mathrm{N}$ fixation in mangrove ecosystems (Gotto \& Taylor 1976, Boto \& Robertson 1990, Sheridan 1991).

The rates found in the present study (Fig. 3) are comparable to previously published rates $(100$ to $200 \mu \mathrm{mol}$ $\mathrm{m}^{-2} \mathrm{~d}^{-1}$ ) from mangrove sediments using both slurry and whole-core $\mathrm{C}_{2} \mathrm{H}_{2}$ techniques (Hicks \& Silvester 1985, Iizumi 1986, Boto \& Robertson 1990). The present data therefore confirm that mangrove sediments support relatively low $\mathrm{N}$ fixation compared with most intertidal sediments (e.g. seagrass beds and saltmarshes) from temperate climates (Capone 1988, Howarth et al. 1988, Welsh et al. 1996). However, in the present mangrove sediment, the microbial nitrogen supply ( $\mathrm{N}$ fixation) seems to be up to an order of magnitude higher than the nitrogen loss (nitrificationdenitrification) (Table 2 ).

The 30 to $60 \%$ reduction in $\mathrm{N}$ fixation after addition of molybdate to the slurries indicates that sulfate reducing bacteria contributed significantly to sediment $\mathrm{N}$ fixation (Fig. 3). For comparison, Welsh et al. (1996) found that addition of molybdate to slurries inhibited $\mathrm{N}$ fixation by more than $75 \%$ in sediments from seagrass beds. Sulfate reducers have previously been proposed to be the most important heterotrophic $\mathrm{N}$-fixing group of organisms in marine sediments (Herbert 1975, Nedwell \& Aziz 1980). Zuberer \& Silver (1975) found that the most numerous $N$-fixing organism in mangrove sediments from Florida (USA) was the sulfate reducing bacteria of the genus Desulfovibrio.

$\mathrm{NH}_{4}{ }^{+}$can be quite important in regulating $\mathrm{N}$ fixation in aquatic environments due to repression of nitrogenase synthesis and a rapid and reversible inhibition of nitrogenase activity (Capone 1988). Since concentrations of $\mathrm{NH}_{4}{ }^{+}$are generally much higher in sediments than in water columns, $\mathrm{NH}_{4}{ }^{+}$inhibition of $\mathrm{N}$ fixation should be of more general significance in sediments. Studies of sedimentary $\mathrm{N}$ fixation have reported a threshold concentration for inhibition by $\mathrm{NH}_{4}{ }^{+}$of 100 to $200 \mu \mathrm{M}$ (Carpenter et al. 1978, Teal et al, 1979). Nonetheless, in the present study no inhibition was observed when the $\mathrm{NH}_{4}{ }^{+}$concentration was increased from around $25 \mu \mathrm{M}$ to about $2 \mathrm{mM} \mathrm{NH}_{4}{ }^{+}$(Fig. 3), suggesting a high degree of $\mathrm{NH}_{4}{ }^{+}$insensitivity by mangrove N-fixing organisms. Similarly, Welsh et al. (1997) found that although $\mathrm{N}$ fixation in seagrass sediments was inhibited by $60 \%$ when the $\mathrm{NH}_{4}{ }^{+}$concentration was increased from 0 to $50 \mu \mathrm{M}$, only little further inhibition occurred at concentrations up to $1 \mathrm{mM}$. This trend has been confirmed by culture studies, where a number of N-fixing organisms, including Desulfovibrio sp., appeared $\mathrm{NH}_{4}{ }^{+}$insensitive (Welsh et al. 1997). It is likely that factors other than $\mathrm{NH}_{4}{ }^{+}$inhibition are responsible for the low rates of $\mathrm{N}$ fixation in mangrove sediments. 


\section{Conclusions}

Transformation rates and fluxes of dissolved inorganic nitrogen were low in sediments of the Ao Nam Bor mangrove. As indicated in the tentative $\mathrm{N}$ budgets in Fig. 4, darkened and inundated sediments imported more inorganic nitrogen by $\mathrm{N}$ fixation and uptake of $\mathrm{NH}_{4}{ }^{+}$and $\mathrm{NO}_{3}{ }^{-}$than was lost by denitrification. Accordingly, both the vegetated (Stn 2) and the non-vegetated (Stn 3) sediments acted as sinks for nitrogen due to autotrophic and heterotrophic microbial assimilation in these nitrogen-deprived environments. The presence of trees in the vegetated sediment was evident as a $50 \%$ higher net sediment retention of inorganic nitrogen, mostly due to assimilation during microbial degradation of nitrogen-poor litter and uptake by tree roots. However, it should be noted that the budgets in Fig. 4 do not represent 'true' diurnal values since (1) the blockage of $\mathrm{NH}_{4}{ }^{+}$ and $\mathrm{NO}_{3}{ }^{-}$fluxes across the sediment surface during air exposure is ignored, and (2) DIN fluxes into the sediment as well as nitrification-denitrification may be enhanced in light due to microphytobenthic activity (Rysgaard et al. 1995).

Based on estimates of net primary production (microphytobenthos and Rhizophora apiculata) at Ao Nam Bor (Kristensen et al. 1995), dark $\mathrm{NH}_{4}{ }^{+}$and $\mathrm{NO}_{3}{ }^{-}$uptake by the sediment may account for $9 \%$ of the primary producers' nitrogen requirements in the vegetated area, while $\mathrm{NH}_{4}{ }^{+}$efflux counteracted $\mathrm{NO}_{3}{ }^{-}$ uptake so that the sediment-water fluxes in the nonvegetated area contributed only $0.1 \%$ of the required nitrogen. The value found here for the vegetated area is about twice the estimated contribution of dissolved nitrogen fluxes in an Australian mangrove forest (Boto \& Wellington 1988). Despite the some degree of uncertainty, the estimated heterotrophic $\mathrm{N}$ fixation in the sediment was equivalent to 7 and $10 \%$ of the net demand by primary producers in the vegetated and the non-vegetated areas, respectively. The former value is about 2 times higher than found by Boto \& Robertson (1990). These authors also estimated that $\mathrm{N}$ fixation by all other structures in mangrove forests may be equal to the sediment contribution. Assuming the same here, $\mathrm{N}$ fixation in the vegetated area at Ao Nam Bor should account for up to $14 \%$ of the plant demand. Nitrification and denitrification, on the other hand, were insignificant in the mangrove sediments, as these processes only transformed inorganic nitrogen equivalent to less than $1 \%$ of net plant requirement. Consequently, as DIN fluxes and $\mathrm{N}$ fixation only provided up to $30 \%$ of the nitrogen requirement of primary producers, there must be other sources of nitrogen. Direct input of nitrogen as both precipitation and dry fall may
Stn 2 (vegetated)

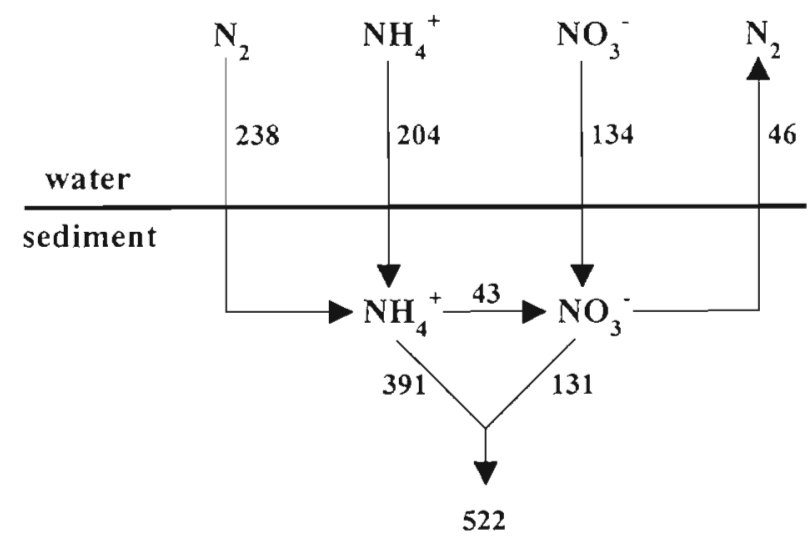

\section{Stn 3 (non-vegetated)}

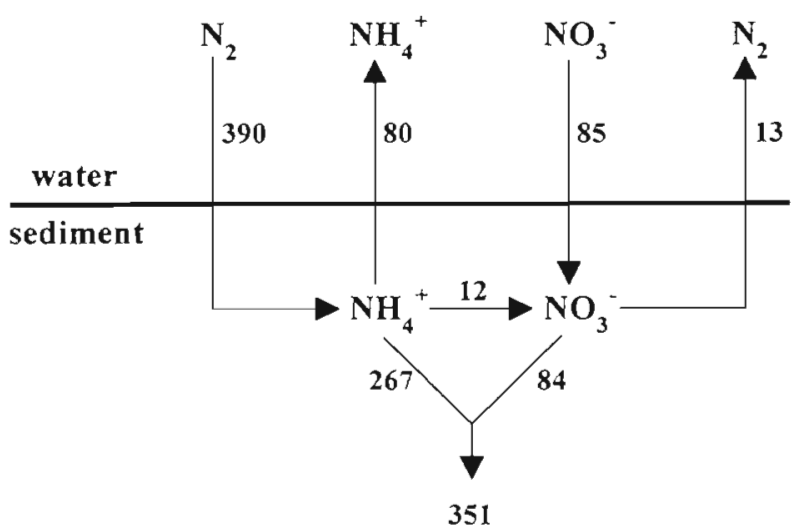

Fig. 4. A flow diagram of rates and links between the processes examined here in vegetated (Stn 2) and non-vegetated (Stn 3) sediments from the Ao Nam Bor mangrove forest. Numbers, which are only representative of darkened and inundated sediments, refer to area-specific rates (in $\mu$ mol $\left.m^{-2} d^{-1}\right)$

contribute (e.g. Paerl 1993), but the low fluxes and process rates strongly indicate a major contribution by a tight coupling between mineralization and assimilation. Thus, nutrients in Ao Nam Bor sediments appear to be rapidly recycled with limited new supplies and losses.

Acknowledgements. We are grateful to the staff af PMBC in general and N. Bussarawit in particular for providing facilities and invaluable assistance during this study. We thank $\mathrm{H}$. Brandt for technical assistance. Our gratitude is also due to L. P. Nielsen for providing mass spectrometric ${ }^{15} \mathrm{~N}$ analysis. This work was supported by grant no. 91-0542/60 from the Carlsberg Foundation. 


\section{LITERATURE CITED}

Alongi DM (1988) Bacterial productivity and mucrobial biomass in tropical mangrove sediments. Microb Ecol 15:59-79

Alongi DM (1989) The role of soft-bottom benthic communities in tropical mangrove and coral reef ecosystems. Rev Aquat Sci 1:243-280

Alongi DM (1996) The dynamics of benthic nutrient pools and fluxes in tropical mangrove forests. J Mar Res 54:123-148

Alongi DM, Boto KG, Robertson AI (1992) Nitrogen and phosphorus cycles. In: Robertson AI, Alongi DM (eds) Tropical mangrove ecosystems. Coastal and Estuarine Studies 41. American Geophysical Union, Washington, DC, p $251-292$

Alongi DM, Christoffersen $P_{1}$ Tirendi $F(1993)$ The influence of forest type on microbial- nutrient relationships in tropical mangrove sediments. J Exp Mar Biol Ecol 171:201-223

Armstrong FA, Stearns CR, Strickland JD (1967) The measurement of upwelling and subsequent biological processes by means of the Technicon Autoanalyzer and associated equipment. Deep Sea Res 14:381-389

Belser LW, Mays EL (1980) Specific inhibition of nitrite oxidation by chlorate and its use in assessing nitrification in soils and sediments. Appl Environ Microbiol 39:505-510

Blackburn $\mathrm{TH}$, Christensen D, Fanger AM, Henriksen $\mathrm{K}$, Iizumi $H$, Iversen $N$, Limpsaichol P (1987) Mineralization processes in mangrove and seagrass sediments. In: Hylleberg $J$ (ed) Ao Yon - a mangrove in the Andaman Sea. Institute of Ecology and Genetics, University of Aarhus, Aarhus, p 22-32

Boto KG, Robertson AI (1990) The relationship between nitrogen fixation and tidal exports of nitrogen in a tropical mangrove system. Estuar Coast Shelf Sci 31:531-540

Boto K, Saffigna P, Clough B (1985) Role of nitrate in nitrogen nutrition of the mangrove Avicennia marina. Mar Ecol Prog Ser 21:259-265

Boto KG, Wellington JT (1983) Phosphorus and nitrogen nutritional status of a northern Australian mangrove forest. Mar Ecol Prog Ser 11:63-69

Boto KG, Wellington JT (1988) Seasonal variations in concentrations and fluxes of dissolved organic and inorganic materials in a tropical, tidally-dominated, mangrove waterway. Mar Ecol Prog Ser 50:151-160

Burdige DJ (1989) The effects of sediment slurrying on microbial processes, and the role of amino acids as substrates for sulfate reduction in anoxic marine sediments. Biogeochemistry $8: 1-23$

Caffrey JM, Kemp WM (1992) Influence of the submerged plant, Potamogeton perfoliatus, on nitrogen cycling in estuarine sediments. Limnol Oceanogr 37:1483-1495

Capone DG (1988) Benthic nitrogen fixation. In: Blackburn TH, Sorensen $J$ (eds) Nitrogen cycling in coastal marine environments. John Wiley, Chichester, p 85-123

Carpenter EJ, van Raalte CD, Valiela I (1978) Nitrogen iixation by aigae in a Massachusetts scilt marsh. Limnol Oceanogr 23:318-327

Chansang $H_{t}$ Poovachiranon $S$, Wungboonkong $C$ (1982) Human impact on a mangrove forest on Phuket Island, Thailand. Biotrop Spec Publ 17:45-54

Corredor JE, Morell JM (1994) Nitrate depuration of secondary sewage effluents in mangrove sediments. Estuaries 17:295-300

David KAV, Apte SK, Banerjı A. Thomas J (1980) Acetylene reduction assay for nitrogenase activity: gas chromatographic determination of ethylene per sample in less than one minute Appl Environ Microbiol 39:1078-1080

Fenchel T, Blackburn TH (1979) Bacteria and mineral cycling
Academic Press, London

Gotto JW, Taylor BF (1.976) $\mathrm{N}_{2}$ fixation associated with decaying leaves of the red mangrove (Rhizophora mangle). Appl Environ Microbiol 31:781-783

Hansen JI, Henriksen K. Blackburn TH (1981) Seasonal distribution of nitrifying bacteria and rates of nitrification in coastal marine sediments. Microb Ecol 7:297-304

Hatcher BG, Johannes RE, Robertson AI (1989) Review of research relevant to conservation of shallow tropical marine ecosystems. Oceanogr Mar Biol Annu Rev 27. $337-414$

Henriksen K, Hansen JI, Blackburn TH (1981) Rates of nitrification, distribution of nitrfying bacteria, and nitrate fluxes in different types of sediment from Danish waters. Mar Biol 61:299-304

Henriksen K, Kemp WM (1988) Nitrification in estuarine and coastal marine sediments. In: Blackburn TH, Sørensen J (eds) Nitrogen cycling in coastal marine environments John Wiley, Chichester, p 207-249

Herbert RA (1975) Heterotrophic nitrogen fixation in shallow estuarine sediments. J Exp Mar Biol Ecol 18:215-225

Hicks BJ, Silvester WB (1985) Nitrogen fixation associated with the New Zealand mangrove (Avicennia marina (Forsk.) Vierh. var. resinifera (Forst. f.) Bakh.). Appl Environ Microbiol 49:955-959

Howarth RW, Marino R, Lane J, Cole JJ (1988) Nitrogen fixation in freshwater, estuarine, and marine ecosystems. 1 Rates and importance. Limnol Oceanogr 33:669-687

Iizurni H (1986) Soil nutrient dynamics. In: Cragg S, Polunin N (eds) Workshop on mangrove ecosystem dynamics. UNDP/UNESCO Regional Project, New Delhi, p 171-180

Jorgensen BB (1978) A comparison of methods for the quantification of bacterial sulfate reduction in coastal marine sediments. Geomicrobiol J 1:11-27

Kaplan WA (1983) Nitrification. In: Carpenter JE, Capone DG (eds) Nitrogen in the marine environment. Academic Press, New York, p 139-190

Koike I, Sorensen J (1988) Nitrate reduction and denitrification in marine sediments. In: Blackburn $\mathrm{TH}$, Sørensen J (eds) Nitrogen cycling in coastal marine sediments. John Wiley, Chichester, p 251-273

Kristensen E (1988) Benthic fauna and biogeochemical processes in marine sediments: microbial activities and fluxes. In: Blackburn TH, Sørensen J (eds) Nitrogen cycling in coastal marine sediments. John Wiley, Chichester, p 275-299

Kristensen E (1990) Characterization of biogenic organic matter by stepwise thermogravimetry (STG). Biogeochemistry 9:135-159

Kristensen E (1993) Seasonal variation in benthic community metabolism and nitrogen dynamics in a shallow, organic poor Danish lagoon. Estuar Coast Shelf Sci 36:565-586

Kristensen E, Andersen FO, Kotoed LH (1988) Preliminary assessment of benthic community metabolism in a southeast Asian mangrove swamp. Mar Ecol Proq Ser 48 $137-145$

Kristensen E, Holmer M, Banta GT, Jensen MH, Hansen $K$ (1995) Carbon, nitrogen and sulfur cycling in sediments of the Ao Nam Bor mangrove forest, Phuket, Thailand: a review. Phuket Mar Biol Cent Res Bull 60:37-64.

Kristensen E, Holmer M. Bussarawit N (1991) Benthic metabolism and sulfate reduction in a southeast Asian mangrove swamp. Mar Ecol Prog Ser 73:93-103

Kristensen E. King GM, Holmer M, Banta GT, Jensen MH, Hansen K, Bussarawit N (1994) Sulfate reduction, acetate turnover and carbon metabolism in sediments of the Ao Nam Bor mangrove, Phuket, Thailand. Mar Ecol Prog 
Ser 109:245-255

Macintosh DJ (1996) Mangroves and coastal aquaculture doing something positive for the environment. Aquaculture Asia, October-December 1996:3-8

Morell JM, Corredor JE (1993) Sediment nitrogen trapping in a mangrove lagoon. Estuar Coast Shelf Sci 37:203-212

Nedwell DB (1975) lnorganic nitrogen metabolism in a eutrophicated tropical mangrove estuary. Water Res 9 $221-231$

Nedwell DB, Aziz SAA (1980) Heterotrophic nitrogen fixation in an intertidal salt marsh sediment. Estuar Coast Mar Sci 10:699-702

Nedwell DB, Blackburn TH, Wiebe WJ (1994) Dynamic nature of the turnover of organic carbon, nitrogen and sulphur in the sediments of a Jamaican mangrove forest. Mar Ecol Prog Ser 110:223-231

Nielsen LP (1992) Denitrification in sediment determined from nitrogen isotope-pairing. FEMS Microbiol Ecol 86 $357-362$

Nixon SW (1981) Remineralization and nutrient cycling in coastal marine ecosystems. In: Neilson BJ, Cronin LE (eds) Estuaries and nutrients. The Humana Press, Clifton p 111-138

O'Donohue MJ, Moriarty DJW, Mac Rae IC (1991) Nitrogen fixation in sediments and the rhizophere of the seagrass Zostera Capricorni. Microb Ecol 22:53-64

Paerl HW (1993) Emerging role of atmospheric nitrogen deposition in coastal eutrophication: biogeochemical and trophic perspectives. Can J Aquat Sci 50:2254-2269

Por FD (1984) The ecosystem of the mangal: general considerations. In: Por FD, Dor I (eds) Hydrobiology of the mangal. W Junk Publ, The Hague, p 1-14

Reddy KR, Patrick WH Jr, Lindau CW (1989) Nitrificationdenitrification at the plant root-sediment interface in wetlands. Limnol Oceanogr 34:1004-1013

Rivera-Monroy VH, Day JW, Twilley RR, Vera-Herrera F, Coronado-Molina C (1995a) Flux of nitrogen and sediment in a fringe mangrove forest in Terminos Lagoon Mexico. Estuar Coast Shelf Sci 40:139-160

Rivera-Monroy VH, Twilley RR (1996) The relative role of denitrification and immobilization in the fate of inorganic nitrogen in mangrove sediments (Terminos Lagoon, Mexico). Limnol Oceanogr 41:284-296

Rivera-Monroy VH, Twilley RR, Boustany RG, Day JW, VeraHerrera F, Ramirez MC (1995b) Direct denitrification in mangrove sediments in Terminos Lagoon, Mexico. Mar Ecol Prog Ser 126:97-109

Rysgaard S, Christensen PB, Nielsen LP (1995) Seasonal variation in nitrification and denitrification in estuarine sediment colonized by benthic microalgae and bioturbat-

Editorial responsibility: Tom Fenchel,

Helsingor, Denmark ing infauna. Mar Ecol Prog Ser 126:111-121

Rysgaard S, Risgaard-Petersen N, Nielsen LP, Revsbech NP (1993) Nitrification and denitrification in lake and estuarine sediments measured by the ${ }^{15} \mathrm{~N}$ dilution technique and isotope pairing. Appl Environ Microbiol 59:2043-2098

Seitzinger SP, Garber JH (1987) Nitrogen fixation and ${ }^{5} \mathrm{~N}_{2}$ calibration of the acetylene reduction assay in coastal marine sediments. Mar Ecol Prog Sur 37:65-73

Shaiful AAA, Abdul Manan DM, Ramli MR, Veerasamy R (1986) Ammonification and nitrification in wet mangrove soils. Malay J Sci 8:47-56

Sheridan RP (1991) Epicaulous, nitrogen-fixing microepiphytes in a tropical mangal community, Guadeloupe French West Indies. Biotropica 23:530-541

Solorzano L (1969) Determination of ammonia in natural waters by the phenolhypochlorite method. Limnol Oceanogr 14:799-801

Stanley SO, Boto KG, Alongi DM, Gillan FT (1987) Composition and bacterial utilization of free amino acids in tropical mangrove sediments. Mar Chem 22:13-30

Stewart WPD, Fitzgerald GP. Burris RH (1967) In situ studies on $\mathrm{N}_{2}$ fixation using the acetylene reduction technique Proc Natl Acad Sci US 58:2071-2078

Strickland JDH, Parsons TR (1972) A practical handbook of sea-water analysis, 2nd edn. Fish Res Bd Can Bull 167

Teal TM, Valiela I, Berlo D (1979) Nitrogen-fixation by rhizosphere and free-living bacteria in salt marsh sediments Limnol Oceanogr 24:126-132

Twilley RR, Lugo AE, Patterson-Zucca C (1986) Litter production and turnover in basin mangrove forests in Southwest Florida. Ecology 67:670-683

Welsh DT, Bourgues S, de Wit R, Auby I (1997) Effect of plant photosynthesis, carbon sources and ammonium availability on nitrogen fixation rates in the rhizosphere of Zostera noltii. Aquat Microb Ecol 12:285-290

Welsh DT, Bourgues S, de Wit R, Herbert RA (1996) Seasonal variations in nitrogen-fixation (acetylene reduction) and sulphate-reduction rates in the rhizosphere of Zostera nolti: nitrogen fixation by sulphate-reducing bacteria. Mar Biol 125:619-628

Wiebe WJ (1989) Phosphorus, sulfur, and nitrogen cycles in mangrove forests. In: Hattori $T$, Ishida $Y$, Maruyama $Y$ Monta RY, Achida A (eds) Recent advances in microbial ecology. Japan Sci Soc Press, Tokyo, p 312-317

Zuberer DA, Silver WS (1975) Mangrove-associated nitrogen fixation. In: Walsh GE, Snedaker SC, Teas HJ (eds) Proceedings of the International Symposium on Biology and Management of Mangroves. Institute of Food and Agricultural Sciences, University of Florida, Gainesville, p $643-653$

Submitted: August 14, 1997; Accepted: February 6, 1998 Proofs received from author(s): May 22, 1998 